DOI: $10.1515 /$ abcsj-2015-0007

\title{
Remapping the Constellation of Walter Benjamin's Allegorical Method
}

\author{
JACK WONG \\ Nova Scotia College of Art and Design University
}

\begin{abstract}
The now-longstanding academic revival of allegory, as well as its import as a perennial buzzword of contemporary art criticism, owes much to a group of essays published in the journal October in the early 1980s. Authors Craig Owens and Benjamin Buchloh, in turn, drew a bloodline to the ideas of allegory that occupied Walter Benjamin throughout his literary career. However, whereas Benjamin saw allegory as the expression of a radical, indeed messianic, view of political possibility, the October writers found in allegory a counter-paradigm against Modernism that would resist the latter's totalizing tendencies by pursing its own deconstructive fate of "lack of transcendence." In the following essay, I trace the source of this discrepancy to the crucial theological underpinnings of Benjamin's concept of allegory, without which the allegorical forms - appropriation and montage - produce not miraculous flashes of unmediated recognition but the permanent impossibility of communication.
\end{abstract}

Keywords: Allegory, Walter Benjamin, postmodernism, theology, messianism, dialectics, deconstruction, constellation, ruin, Trauerspiel

The 1980s ushered a wave of critical interest in characterizing the changes in art of the previous decade-a shift then already provisionally (and contentiously) termed "postmodernism." In the fore were several critics/theorists associated with the journal October (MIT Press). Douglas Crimp's "Pictures," published at the cusp of this moment, sought to give definition to the break with Modernism's preoccupation with medium specificity towards practices that shifted between mediums, which at the same time abandoned critic Michael Fried's argument for the modernist 
work's transcendent "presentness" in favour of a "theatricality" which was (explicitly or implicitly) experienced through time. Warning of a danger in simply equating postmodernism with a defeatist pluralism, Crimp was among the first to identify that certain artists were working between mediums in order specifically to make "pictures all the more picturelike, to fix forever in an elegant object our distance from the history that produced these images. That distance is all that these pictures signify" (85).

Crimp's description-and his essay as a whole-is a forerunner to a theoretical paradigm that would next be elaborated by Craig Owens in his essay in two parts, "The Allegorical Impulse: Toward a Theory of Postmodernism" (1980). Following the recent retrieval (in the neighbouring disciplines of literature, architecture, and art history) of allegory from the dumping ground of outmoded aesthetic conventions, Owens begins by positing that allegory occurs "whenever one text is doubled by another" (68). This presents an ideal framework with which to examine new artistic modes all exhibiting (in one way or another) a shift from authorial production to strategies of appropriating existing material indeed, his first correlation between the new artistic strategies and allegory is that

Allegorical imagery is appropriated imagery; the allegorist does not invent images but confiscates them. He lays claim to the culturally significant, poses as its interpreter. And in his hands the image becomes something other... He does not restore an original meaning that may have been lost or obscured... Rather, he adds another meaning to the image. If he adds, however, he does so only to replace... (69)

Owens identifies additional links between allegory and contemporary art in site specificity (in its "tendency to engage in a reading of the site," the local history and mythology of which serves as the base text), in photography (in which "our desire to fix the transitory, the ephemeral, in a stable and stabilizing image" becomes the subject of the photograph, doubling - in the case of Atget and Walker Evans, displacing - the pictorial content), and in strategies of accumulation present in photomontage and Conceptualism (any meaning in which obtains not from the accumulated things themselves, but from a second, higher-order 
source - the structure of which the things are a function) (69-72). This last link demonstrates that allegory is the "epitome of counter-narrative": where narrative is the horizontally-oriented chain of events, allegory "arrests narrative in place" by "superinducing" a reading of the correspondences between vertically-adjacent chains (the analogy in rhetoric being metaphor and metonym) (72). However, Owens invokes Joel Fineman's analysis (presented in the same issue of October) that allegory does not align with one or the other, but "cut[s] across and subtend[s] all such stylistic categorizations." This feeds directly into Owens's central thesis: by demonstrating allegory's "blatant disregard for aesthetic categories," its unhindered traversal between the horizontal axis of metaphor and the vertical axis of metonym, its conflation of the visual and verbal (images are read, as in a hieroglyph; words are concretized, as in a palimpsest), Owens forwards allegory as "a single, coherent impulse" underlying postmodernism, by which the diverse strategies of postmodern art can be recast to form a whole (75).

Part 2 of "The Allegorical Impulse" sees Owens refining the compass of his project, which had been cast so widely in the first installment of the essay. In particular, he argues that allegory is concerned not with ambiguous, multiple meanings engendered by a single sign, but rather "two clearly defined but mutually incompatible readings [that] are engaged in blind confrontation in such a way that it is impossible to choose between them" ("Part 2," 61). As an example, he cites an image from Laurie Anderson's performance Americans on the Move (1979): a graphic representation of a nude man and woman, the man's right arm raised at the elbow, his palm opened forward. This graphic, which had been emblazoned on the Apollo 10 spacecraft, was now projected onto Anderson's stage, with the commentary: "In our country, we send pictures of our sign language into outer space... Do you think they will think his hand is permanently attached that way? Or do you think they will read our signs?" (60) As Owens notes, this is what Paul de Man understands as a "structural interference of two distinct levels or usages of language, literal and rhetorical (metaphoric)" (63). De Man's schema would make the two levels easily distinguishable, were it not for the fact that literal language is itself metaphorical. ${ }^{1}$ A literal reading, the aim of which is to deconstruct a 
metaphorical one, will thus be "inevitably implicated in what [it sets] out to expose" (63), requiring further levels of deconstructive narratives upon itself, the impossibility of a final reading becoming more and more apparent. The result is allegory.

This pattern is characteristic of deconstructive discourse in general. In "On the Museum's Ruins," Crimp had shown the museum to be a contradictory institution, a fundamentally heterogeneous assemblage of "bric-a-brac" demanding of itself a coherent, homogeneous system of knowledge. For Crimp, Rauschenberg's move from techniques of production to reproduction invents a new picture surface "which can receive a vast and heterogeneous array of cultural images and artifacts that had not been compatible with the pictorial field of either premodernist or modernist painting" (44). The "absolute heterogeneity that is the purview of the museum ... is spread across the surface of every Rauschenberg work" (43) - and Rauschenberg's art is thus a deconstruction of the very discourse of the museum. To this, Owens adds that, "if, in his work, Rauschenberg enacts a deconstruction of the museum, then his own deconstructive discourse... can take place only within the museum itself. It must therefore provisionally accept the terms and conditions it sets out to expose" and his canvases "must also declare themselves to be part of the dumping ground they describe" ("Part 2,"71). This repetition of "error" which makes impossible the closure of discourse is taken to be paradigmatic of both deconstruction and allegory, which leads (in Owen's hands) to their mutual conflation. For Owens, reading deconstructionism allegorically raises the discourse above criticisms of its own structural failure, and by the same token the imputation of an allegorical impulse to postmodern art recasts its typically contradictory and opaque nature as "its undeniable pathos, which is also the source of its strength" (71-2).

Benjamin Buchloh picks up this thread in "Allegorical Procedures: Appropriation and Montage in Contemporary Art," originally published in Artforum in 1982. Buchloh's model of allegory is structured like Owens's, the defining features of which are the palimpsest through which one text is read through another, and the "relapse into error" characteristic of deconstructive discourses. Drawing from Karl Marx and Walter Benjamin, Buchloh refigures these features in terms of commodity fetish: 
The allegorical mind sides with the object and protests against its devaluation to the status of a commodity by devaluating it for the second time in allegorical practice. By splintering signifier and signified, the allegorist subjects the sign to the same division of functions [into use value and exchange value] that the object has undergone in its transformation into a commodity. It is this repetition of the original act of depletion and the new attribution of meaning that redeems the object. (29)

The central activity of the allegorist is montage, a particular inflection of artistic appropriation in general which Buchloh finds running through twentieth century art from its Dadaist origins to the work of a new generation of postmodern artists in the late $70 \mathrm{~s}$ and early $80 \mathrm{~s}$. Buchloh calls Duchamp's L.H.O.O.Q. (1919) "one of the first instantiations of a dadaists' allegorical montage, driven by the principle of appropriation" (30-1), while his unaltered ready-mades affect a radical iconoclasm that brings the allegorical transformation of the commodity into an emblem to a full circle. By comparison, the reception of Duchamp's ready-made aesthetic in America would only produce "well-tempered modes of appropriation" which "would always remain one of liberal reconciliation" in the hands of Rauschenberg, Jasper Johns and Andy Warhol (32). By playing Duchamp's allegorical vision against that of his followers, Buchloh slyly sets a stage where radical poststructuralist critique of ideology is the project appropriate to the allegorical impulse, which would only find its proper expression with the advent of 1960s Conceptualism.

The latter part of Buchloh's essay is thus also concerned with the spectrum of political positions available within an allegorical approach. When Sherrie Levine rephotographs a reproduction of an existing modernist work - as she does in After Walker Evans (1981), a copy of a copy of Evans's Allie Mae Burroughs (1936) - she performs “one of the strongest negations of the mythical singularity of the work of art and its indisputable status as a commodity" (42). But, like Warhol before her, Levine's refusal of authorial production is a passive position which remains complacent (and eventually complicit) with the institutions' acculturation at large. On the other hand, the allegorical procedures in Martha Rosler's The Bowery in two inadequate descriptive systems (19745) insist upon a position of cultural activism. In this installation, deadpan 
"documentary" photographs of storefronts in New York's Bowery district are juxtaposed with lists of words typed on white cards that describe the states of drunkenness of the "Bowery bums," a heavily-played feature in modernist street photography of this urban-poor location but which is absent from Rosler's images. This "blind confrontation of antithetical meanings which characterizes the allegory of unreadability," as Owens would put it ("Part 2" 72), performs a deconstruction of the illicit exchange between artist and viewer in photography (and in Conceptualism) premised on class privilege. At the time of its writing, Buchloh estimates that Rosler has placed herself unfavourably within a tradition of politically committed art that fails to communicate by ignoring dominant discursive conventions. What has come to pass, rather, is a situation more like Rauschenberg's, in which Rosler's deconstructive critique contains a margin of error (the reiteration of modes of photography and Conceptualism which would adequately communicate through inadequacy) that allows it to be subsumed by the discourse it sets out to denounce.

I have dwelled upon these particular essays by Crimp, Owens, and Buchloh in the early 1980s to argue that the perimeter of a theory of allegory in visual art was staked out in this moment, and has largely remained the horizon of allegory in visual art practice and criticism since. For one, a characteristic feature of these essays was the absolutely fluid definition of allegory which is taken to be proper to allegory as itself a fluid concept that must resist final meaning. As Gail Day writes, Owens's essays are "far from being a mark of noncommitment" and rather "it is clear how much his interest in the undecidable was part of an overall project" (105). All the same, this is highly strategic, as it substantiates the claim - for Owens especially - that allegory stands in the face of the totalizing tendencies of Modernism, while paradoxically providing an allencompassing paradigm robust enough to account for the disparate tendencies of postmodern and contemporary art production. Thus, subsequent research and commentary on allegory in visual art theory have remained preoccupied, on the one hand, with developing more sophisticated renderings of allegory that continue along the lines of literary, linguistic, and philosophical analysis, while addressing Crimp's 
and Owens's claims that allegorical impulses preside over a distinct discontinuity between Modernism (figured above all in Michael Fried) and postmodernism (this line of critique was initiated, notably, with Stephen Melville's sprawling 1981 essay, "Notes on the Reemergence of Allegory"). On the other hand, "allegory" has become a generalized shorthand for anything resembling appropriation, montage, devalorization, etc. As Day observed, contemporary writing had by the end of the $1990 \mathrm{~s}$ transformed allegory into "fixed tropes and buzz-phrases" that "seem more a feature of intellectual laziness in the face of contemporary art than examples of critical thought, a way of eliding a difficulty rather than facing it" (105).

More important, however, is that the provisional assessments that both Owens and Buchloh made at this moment outlined the political horizon of an allegorical approach. At the ends of their essays, the authors write, respectively:

This deconstructive impulse is characteristic of postmodernist art in general and must be distinguished from the self-critical tendency of modernism.... When the postmodernist work speaks of itself, it is no longer to proclaim its autonomy, its self-sufficiency, its transcendence; rather, it is to narrate its own contingency, insufficiency, lack of transcendence. (Owens, "Part 2" 80)

And,

As we have seen, all the artists discussed here appropriate and quote the images and materials that they use for their allegorical investigations, in the very manner that the radical conceptual artists of the late 1960s had questioned why artistic practice should be relegated to the status of a spectacularized commodity of individuation. If they have been successful in their critiques, it will be only a temporary success - until acculturation will find new ways to accommodate their production. For ultimately, it is the visual representation rather than the textual articulation of a construct that imbues it with material reality: the basis of both the commodity form and institutional acculturation. (Buchloh 50-1)

These pronouncements are not only exemplary of what we are now fully familiar with as postmodernism's ironic self-awareness and melancholic stasis, but - inasmuch as their corresponding theories of 
allegory have presided over postmodern and contemporary criticism of the last three decades - they have also played a key role in shaping this outlook.

This situation would not be possible without the work of the German critic and philosopher Walter Benjamin. As Marina Roy notes in her essay "Speaking in Other Terms: Buchloh's Allegorical Tracings of Post-Conceptual Constellations," allegory-inspired texts cropped up in art theory and criticism around the time of the translation of Benjamin's 1928 book Ursprung des deutschen Trauerspiel (The Origin of German Tragic Drama) into English in 1977. It is in the Trauerspiel book, in which Benjamin analyzed the particular form of German dramatic literature in the Baroque era, that the twentieth century witnessed the first critical treatment of allegory to see it in a redemptive light. That Owens would cite Benjamin at length thus fits into Roy's version of events, but it also fits into Owens's own: beginning his essay by emphasizing the proscription of allegory for nearly two centuries from the romantic era to Jorge Luis Borges, Owens returns at length to this theme. A fine-tuned narrative emerges: allegory's status as a maligned and denigrated aesthetic trope (especially as historically contrasted with the whole, essential, organic symbol) refashions the split that postmodern incredulity wrests from Modernist credo as an underdog prizefight. It is in this light that we recognize Owens's invocation of Benjamin - as well as Benjamin's champion, the mid-nineteenth century poet Charles Baudelaire - as the lynchpin to his argument. He makes explicit his case that Benjamin's insight "effectively situates an allegorical impulse at the origin of modernism in the arts and thus suggests the previously foreclosed possibility of an alternate reading of modernist works, a reading in which their allegorical dimension would be fully acknowledged" ("The Allegorical Impulse" 79). Similarly, Buchloh's apparent indebtedness to Benjamin is clear from the first sentences of "Allegorical Procedures." In an attempt to reconcile Benjaminian allegory to contemporary politics, however, Buchloh finally interprets that Benjamin eventually abandoned his allegorical preoccupations in favour of a "factographic, productivist position" in his later writings, including "The Author as Producer" (44). 
A limited, instrumental approach to Benjaminian theory persists today. What has remained neglected from the essays of the 1980s onwards is that Benjamin's concept of allegory has always - in addition - a bearing on a messianic notion of time and history, an emphasis which for Benjamin is inherent to the structure of allegory. This is already present in the Trauerspiel book, and it becomes all the more apparent in Benjamin's writing on Baudelaire, as well as the rest of his immense unfinished exposé on the Paris arcades, where allegory is the crux of both the content and the form of the project. Allegory was therefore not only a theme in Benjamin's writings, but a permanent strategy in his own literary output. By deriving a theory of allegory that simultaneously divorces it from this larger picture, the critical reception of allegory in the early 1980s has also served to foreclose the radical political insights that may be available to an allegorical approach - as evidenced when Buchloh is finally unable to articulate a position outside of Levine's "melancholic complacency," Rosler's active but marginalized politics, and Dara Birnbaum's complicity somewhere in between. Per the terms laid out in Owens's essay, politics has been found to be supplementary to allegory as allegory was once found to be supplementary to form-and-content.

Howard Eiland and Michael W. Jennings remind us that the "crystallization of history in the present is what Benjamin calls the dialectical image" (614), which, towards the end of Benjamin's life, culminated in his concept of Dialektik im Stillstand. Much of Benjamin's later writings point to the "revolutionary energies" latent in allegory's images of the ruined and obsolete that, as the phrase "dialectic at a standstill" evokes, has the potential to break through into the present, bringing the myth of linear time to a grinding halt. On the other hand, writers like Owens have deemed allegory to be a "fundamentally deconstructive impulse" concomitant with postmodernist tendencies and, as in postmodernism, allegory seems to play out on a plane where a Marxist conception of class consciousness and revolution has already been abandoned in favour of a nihilistic conception of the impossibility of communication ("Part 2"79). In this essay, I examine the disjuncture between Benjamin's concept of allegory and that of the October "revival," arguing that some of the most remote and esoteric themes in Benjamin's 
writing have been cleared away by later writers to yield a tidier concept of allegory for their purposes. These themes - his dedication to theology and mysticism, for example - are simultaneously some of his most important ones, which find their significance precisely through an allegorical mode of elucidation.

When Walter Benjamin restored the allegorical mode for the twentieth century, it was indeed the observable breakdown of guaranteed meaning that, for him, invested it with its critical significance. Benjamin's study of allegory is found in The Origin of the German Tragic Drama, his rejected habilitation thesis (later published as a book in 1928). Various commentators have been careful to translate the dramatic form concerned, the Trauerspiel, as mourning- or lament-play or to retain the original term in German, precisely because Benjamin's is an analysis of a wholly specific form at a specific period in history - the German Baroque which he is at great length to distinguish from the monolithic genre of "tragedy," particularly in the second chapter of the book. To legitimize the Trauerspiel as a genre in its own right, to be judged by a criteria distinct from that of tragedy which had been erroneously applied to it, is only secondary to Benjamin's aims. The book is, above all, a historicalmaterialist elucidation (though not expressed in those terms, for Benjamin had yet to fully engage with Marxism at this point) of the significance of the Trauerspiel in "disclos[ing] an era's will to art and thereby its very spiritual constitution" (Eiland and Jennings 226).

The Trauerspiel is uniquely befitting of this orientation of analysis because it is itself "not rooted in myth but in history" (Steiner 16). Whereas tragedy is grounded in mythological timelessness, acting out an ostensibly universal rite of heroic sacrifice in which its hero is endowed "with the realization that he is ethically in advance of the gods" (16), the Baroque subject lives through a radically secularized age stripped of traditional eschatology, a phenomenon catalogued in Max Weber's seminal study of the consequences of Protestant doctrine. ${ }^{2}$ As George Steiner notes in his introduction to the English translation of the Trauerspiel book, the Baroque dramatist

Feel[s] himself dragged towards the abyss of damnation, a damnation registered in a profoundly carnal sense... [as he clings] fervently to the 
world. The Trauerspiel is counter-transcendental; it celebrates the immanence of existence even where this existence is passed in torment. It is emphatically 'mundane', earth-bound, corporeal. It is not the tragic hero who occupies the centre of the stage, but the Janus-faced composite of tyrant and martyr, of the Sovereign who incarnates the mystery of absolute will and of its victim (so often himself). (16)

The dramatic form that arises from this period is (in broad strokes that can do little justice to Benjamin's analysis) a "presentment of man's suffering and cruelty, made bearable through stately, even absurd form" (24). Steiner notes Benjamin's distinction that tragedy produces tragic feelings in the spectator but fundamentally does not require an audience, aimed inward as it was at a hidden god (17-8); on the other hand, the outward ceremony of lament, ostentation, gesture, and hyperbole in the Trauerspiel demands an audience, for as Benjamin writes they "are not so much plays which cause mourning, as plays through which mournfulness finds satisfaction: plays for the mournful" (Origin 119).

Allegory re-enters the stage in Benjamin's discussion as the personifications of Melancholy and Joy, or saturnine acedia (sloth) (1556). But, as Howard Caygill writes,

Benjamin shows how the crisis of the meaning of life provoked by the Protestant doctrine has objective and subjective consequences in the draining of meaning of the world of objects and actions - the world is no longer a stage of salvation - and with this, the melancholy provoked in the sage or hero who experiences and contemplates the disenchantment of the world. (248)

This is the "ineluctable crisis of meaning that is emerging as the essence of the allegorical" (248). In material terms provided by Eiland and Jennings, the Trauerspiel are "jagged, recondite dramas":

Their halting, wooden actions are driven not by thought or feeling but by "violent physical impulses," while their stilted, often hieratic speech makes manifest their alienation from both nature and grace. ... The inert, hollowed-out figures on the stage, surrounded by objects [props, emblems] deprived of inherent significance, reflect a history no longer distinguishable from nature's own incessant agony and undoing.... These things and thinglike humans can have no intrinsic relation to a meaningful present or to a history of salvation; they are instead invested by the allegorist with a hidden and wholly fallen significance. (228) 
Thus, while the Trauerspiel adopts the recognizable mechanics of conventional allegory, its outlook, which "already suggests a loss of faith in the capacity of the allegorical image to lead to an apprehension of eschatological reality," redefines the orientation of allegorical procedures (Copeland and Struck 8). As Benjamin famously writes in the Trauerspiel book, "[a]ny person, any object, any relationship can mean absolutely anything else" (Origin 175). Dirk Obbink notes that, in ancient Greece, the allegorical reader "[r]ather than try[s] to figure out how poems in general produce their meanings... sets out to find what a particular poem means" (15). The Benjaminian concept of allegory is precisely the reverse. As Eiland and Jennings describe it, allegory has been reconstituted in this paradigm shift as "a strictly codified set of signifiers having no necessary relationship to what is represented" (228). This explains why allegory has proven so appealing to a poststructuralist and postmodern theory preoccupied with the dubious nature of language (the latter being incredulous, in addition, with the dubiousness of all organic narratives). Of course, this notion was itself fundamental to the foundations of semiotic theory, in which there is "no natural or intrinsic correspondence between signifier and signified in the sign" (Plate 48). Subsequent writers have thus had both Benjamin and Ferdinand de Saussure to draw upon.

If there is something missing to this picture, it is the crucial dimension that allegory for Benjamin was never simply a neglected "mode" fit for rehabilitation, nor was it suitable to a critical commentary in the present merely out of an affinity to contemporaneous attitudes; these in themselves provide insufficient reason for Benjamin's dedication to allegorical methods throughout the remainder of his life. For Benjamin, the stakes were much higher for a philosophical criticism rendered through allegorical means: "to make historical content, such as provides the basis of every important work of art, into a philosophical truth" (Origin 182).

Eiland and Jennings write that the book on the Trauerspiel represents, above all, Benjamin's first historically oriented analysis of the origins of modernity: 
Certain features of modernity, in other words, can come to light only through analysis of a reviled, long-past era.... Certain moments in time stand in a synchronous relation to one another, a relation of correspondence; or, as [Benjamin] puts it later, there is a "historical index" such that the character of a particular epoch can sometimes be understood only by confronting it with a distant predecessor. (225)

Steiner puts it similarly: "Thus a study of the baroque is no mere antiquarian, archival hobby: it mirrors, it anticipates and helps grasp the dark present" (24). This is the schematic, in any case - though allegory's real operations, as conceptualized by Benjamin, would be much more enigmatic and elusive, keeping in mind its resistance to a horizontally oriented narration of progressive history.

The fragments of a primal history that both reveals and is revealed in the evolving present is the key motif of Benjamin's later work, including his massive, unfinished project on the Paris arcades of the nineteenth century, Das Passagen-Werk (The Arcades Project). Benjamin would develop this motif into the "dialectical image," of which Eiland and Kevin McLaughlin give an astute characterization:

[T]hat which, under the divinatory gaze of the collector, is taken up into the collector's own particular time and place... Welcomed into a present moment that seems to be waiting just for it - "actualized," as Benjamin likes to say - the moment from the past comes alive as never before. In this way, the "now" is itself experienced as preformed in the "then," as its distillation... The historical object is reborn as such into a present day capable of receiving it, of suddenly "recognizing" it. This is the famous "now of recognizability" (Jetzt der Erkennbarkeit), which has the character of a lightning flash. (xii)

When Theodor W. Adorno read Benjamin's manuscript for "The Paris of the Second Empire in Baudelaire" in 1938, which the latter considered a model for the Arcades Project, Adorno was already intimately familiar with Benjamin's preoccupation with this allegorical form but was dismayed to find that Benjamin's dense accumulations of dialectical images would remain unmediated at large scale in the new exposé. Unable to support its publication in the Zeitschrift für Sozialforschung, the journal published by the Institute of Social Research 
(the "Frankfurt School," then relocated from Frankfurt to New York) of which Adorno was an editor, he questioned in a letter to Benjamin: "can this procedure be applied to the Arcades complex? Panorama and 'trace,' flaneur and arcades, modernity and the ever-same, without theoretical interpretation: Is this 'material' that can wait patiently for interpretation without being consumed by its own aura?" ("Exchange" 100). Though Benjamin would admit that the text was incomplete without the other parts of the book that would explain his "philological procedure," he was also adamant that the section he sent remained as is in its esoteric approach. Therefore the dialectical image as conceived by Benjamin may be said to resemble not only a "lightning flash," but - equally rarefied - a religious prophecy awaiting its fulfillment.

To apprehend political insight from Benjamin's writings in this mode requires the reader to acknowledge him as a figure whose radical worldview was inseparable from its often deeply esoteric expression. This is not an easy task: as Michael Rosen poses,

What could be further removed from what one would normally understand by "materialism" than Benjamin's early writings, with their predilection for mystical theories of language and unblushingly antiscientific metaphysics?... the connection [between Benjamin and Marxism] appears at all plausible only if Marxism, its scientific pretensions notwithstanding, rests upon a mystical view of the world. (40)

What, in fact, the specific "mystical" interests of Benjamin's were is a final question that must be attended to before arriving at a changed view of allegory. A major source of and inspiration for these ideas throughout Benjamin's life is found in Scholem, a scholar of the Kabbalah who in his own right was largely responsible for introducing scholarship around Jewish mysticism to the twentieth century. Their friendship from youth and continued correspondence was a pathway for Benjamin to Kabbalistic thought, as well as to the inflection of questions of politics as questions of epistemology. We see the fruitfulness of this relationship in the case of Benjamin's early essay, "On Language as Such and on the Language of Man" (1916), which was adapted from a letter to Scholem written in a critical stance to the Judaism and Zionism of the day. 
As Brent Plate argues in his book, Walter Benjamin, Religion, and Aesthetics: Rethinking Religion Through the Arts, Kabbalistic thought clearly resonated with Benjamin, who felt he had "stumbled on a radical alternative cosmogony to that of the modern West and found several ideas that paralleled his own religiopolitical concerns" (29). Plate speculates on another dimension introduced by this cosmogony: whereas the Christian orthodoxy conceives of creation as told in Genesis as a one-way process that creates something out of nothing (33), the same text in Hebrew emphasizes the "undifferentiated matter" (tohu wabohu) which existed before the beginning. God's acts of creation did not make existence out of nonexistence, but marked divisions in this originary chaotic matter: to separate land from sea, heaven from earth, and woman from man. A further Kabbalistic telling of creation, from the sixteenth-century Rabbi Isaac Luria, holds that the all-encompassing God (Ein-Sof) had first to contract itself to make room for the world to exist - the act of creation was not "giving" but taking away, and the world thus created was an absence or void (27-30). After this process of reduction, Ein-Sof began to fill the forms ("vessels") left in the void from Its withdrawal with divine light, but this light was too much for the vessels, and they fragmented into many pieces - one might say, ruins - that dispersed across the material world. ${ }^{3}$ The final activity was "the orientation toward the future, the healing and putting together of the fragmented world" (32). According to Luria, it is only through humans that the world can be mended, and thus humans are implicated in Creation - and redemption. Significantly, this has implications for eschatology, which provides a key intersection of theology and Marxism, insofar as the latter is also involved (however ambivalently) with imagining an overcoming of history. Plate notes, citing Marc-Alain Ouaknin, that in the final mending (tikkun) described by the Lurianic Kabbalah is a political and humanistic notion that "the Messiah is not he who produces redemption, but only the manifestation of his success. One can no longer await the Messiah; one must create him" (Ouaknin qtd. in Plate 32).

Plate sees the dialectic of destruction and creation as one of the key ideas that Benjamin extracted from Kabbalistic literature and reinterpreted for his own purposes. "For Benjamin," he writes, "destruction lies at the 
heart of creation, and to get to truth, the boundaries imposed at creation must be taken apart" (28). We find this in Benjamin's fragment "The Destructive Character" (1931):

The destructive character sees nothing permanent. But for this very reason he sees ways everywhere. Where others encounter walls or mountains, there, too, he sees a way. But because he sees a way everywhere, he has to clear things from it everywhere.... Because he sees ways everywhere, he always positions himself at crossroads. No moment can know what the next will bring. What exists he reduces to rubble, not for the sake of the rubble, but for that of the way leading through it. (302-3)

The flipside of the dialectic - creation from destruction - is figured in the concepts of ruin, constellation, and the dialectical image.

The critical themes that Benjamin drew from the well of mysticism are manifold and complex. For him, these theological investigations provided access to a realm of conceptualizing that was foreclosed by the tyranny of rational Enlightenment thought. The result, particularly in Benjamin's early esoteric works, is a vision of the hope for mankind's redemption, which haunts the politics of the now but nevertheless is presented in unmediated terms - this being its most unsettling quality. Richard Wolin summarizes this worldview, faithfully to Benjamin's explicitly theological language, as follows:

At issue is the "fallen" character of human history, which takes on the appearance of "natural history," a history that is consigned to an inexorable fate of decay and decline. The subjective corollary of this fate is [the] inescapable network of guilt which originates with man's expulsion from Paradise and which serves as a ceaseless testimony to the seemingly infinite distance that separates historical man from the state of grace represented by the Messianic era. Benjamin takes his stand, initially, in the midst of profane life. And from his lowly station in the fallen historical world, he sifts through the ruins of bygone ages for traces of redeemed life in the hope that if these traces can be renewed for the present, the link between the Messianic era, the key to which is mysteriously inscribed in man's past, and the present era, however godforsaken it may appear, can be, if not guaranteed, at least prevented from fading into oblivion. (107)

It is in this sense that, however distant from the concerns of historical materialism as it may seem, theology plays its counterpart, 
providing a radical eschatological conception of revolution as a Messianic realization that is not the goal of "progress," but the task of now-time; not "the culmination of history, but rather its termination, a qualitative leap into a realm beyond history," to which organic movement from the present stage is impossible (57-8). As such, the transcendental knowledge of theology remained for Benjamin a real object of philosophy - indeed its proper object - which at the same time elaborates on Marxism in opposition to its dominant scientific interpretation which rendered the overcoming of capitalism as an inevitable empirical outcome.

We return once more to allegory, about which I will make two final points. First: that the theological element in Benjamin's work, when it intersects with materialist concerns, is necessarily allegorical (as Wolin's image of Benjamin "sift[ing] through the ruins of bygone ages" makes clear). Secondly: that contained within Benjamin's dialectical image is not only the flash of recognizing the historical object in the present, as previously acknowledged, but that this flash releases a revolutionary energy. For, even the choice of terminology - Benjamin himself expresses this in terms of danger and shock - signals the jarring character of the "moment of readability." Benjamin's choice of historical subject - the Paris of the Second Empire - now assumes its full significance: the fragments of this era "would shimmer before the reader like the flash thoughts of a memory, and the ghost that haunted their ruins in the present was the ghost of a failed revolution, the unfulfilled dream of a classless society [emphasis mine]" (Buck-Morss 146). In mystical fashion, Benjamin sees this unfulfilled dream as a dream stored in the unconscious of the collective, leaving its trace in every piece of history, unintelligible by themselves but which gain their significance through the constellationmaking activity of allegory. "[T]races of utopia, engendered in the intersection or collision of the new and the antiquated, can be read off of untold aspects of contemporary society," the untold - the outmoded and neglected memories, such as that of the Parisian ragpicker who once "fascinated his epoch" - being key (Eiland and Jennings 491). Benjamin's conviction is that these motifs, the "seemingly inconsequential details of large historical structures, have been ignored as the dominant class ascribes truth-value to its own, ideologically inspired version of history" 
(613). The escape of these details from the oppressive control of traditional historiography accounts for the revolutionary energy preserved intact within. As Benjamin writes, the "tiger's leap into the past" that constitutes the dominant history "takes place in an arena where the ruling class gives the commands." But the "same leap in the open air of history is the dialectical leap Marx understood as revolution" ("On the Concept of History" 395).

"On the Concept of History" (1940), the last written draft by Benjamin before his death, captures with great urgency the need to explode the notion of the dominant ideology's monopoly over historical time, for precisely "a sense of historical destiny had lured people into the catastrophes of fascism and war" (Buck-Morss 168). His method of a dialectic at a standstill (Dialektik im Stillstand) reaches its greatest expression in the final theses:

Thinking involves not only the movement of thoughts, but their arrest as well. Where thinking suddenly comes to a stop in a constellation saturated with tensions, it gives that constellation a shock, by which thinking is crystallized as a monad. The historical materialist approaches a historical object only where it confronts him as a monad. In this structure he recognizes the sign of a messianic arrest of happening, or (to put it differently) a revolutionary chance in the fight for the oppressed past. He takes cognizance of it in order to blast a specific era out of the homogeneous course of history; thus, he blasts a specific life out of the era, a specific work out of the lifework. (Benjamin, "On the Concept of History" 396)

The (now longstanding) revival of interest in Walter Benjamin's work in academia is well-noted by virtually all the authors cited in this essay: here is the idiosyncratic, unorthodox character, the "Last Intellectual", for whom, as some critics would have it, "philosophy and literature [were] not mere parlor games, but for whom these serve[d] as the focal point, the raison d'etre of life" (Wolin $x$ ). ${ }^{4}$ Yet, removed from the urgencies of his era, contemporary scholars have drawn an uneasy relationship with the revolutionary energy latent in Benjamin's writing. The task of domesticating Benjamin's radical politics for the liberal academy has been made easier thanks to his often oblique program of theorizing, which allows one to claim it as merely an undercurrent, or at 
least obscure it as such. Benjamin's mysticism, in itself, is not the problem: Rosen, for example, willfully reads "On the Programme of the Philosophy to Come" (1918) to view Benjamin's apparently antiscientific metaphysics as ultimately a project of extending Kant's restricted conception of experience to include those mental and psychological perceptions outside of empirically-oriented cognitive experience. Benjamin, according to Rosen, fundamentally accepts the transcendental turn that Kant gives to philosophy, and thus "even at his most mystical and apparently antiscientific, Benjamin's chief concern is Kantian" (44). The dubious conclusion is that Benjamin's particular point of view is "Marxist-Kantian", which at the same time completes Rosen's project of stripping Benjamin of his link to Hegelianism ("these are incompatible with [Benjamin's] theory and, as can be seen, he clearly rejects them"; at the same time, Adorno comes off being the Hegelian-Marxist) and disempowering his writing of its eschatological orientation towards an "end of history," via Hegelian dialectics or otherwise (53).

It is in this light that we can return, finally, to the allegorical procedures as conceived by Owens et al., pausing first at the contention one might raise that Owens equally elaborated upon the themes I have stressed in Benjamin's writings, invoking as he does in his opening epigraph of "The Allegorical Impulse" the same passage from Benjamin as I cited above: "Every image of the past that is not recognized by the present as one of its own concerns threatens to disappear irretrievably." 5 Early on in Part 1 of Owens's essay, he contests Jorge Luis Borges's estimation that allegory is part of an outmoded past that our tastes have since left behind, charging Borges with "[denying] allegory what is most proper to it: its capacity to rescue from historical oblivion that which threatens to disappear" (68). Owens continues: "Allegory first emerged in response to a similar sense of estrangement from tradition; throughout its history it has functioned in the gap between a present and a past which, without allegorical reinterpretation, might have remained foreclosed" (68). Yet, as I argued above, it is clear the extent to which Owens oriented the signposts left by Benjamin, Baudelaire, and others towards his own narrative of oppression and redemption - where the historical content of allegory is conflated with allegory's own recession "into the depths of 
history" (68), and where allegory can comprise both the means and the object of its own rescue - and to what extent Owens's own concept of allegory is meaningfully informed by Benjamin's dialectical insight.

When, in the closing lines of his essay Owens writes that the postmodernist work speaks of itself to tell "of a desire that must be perpetually frustrated, an ambition that must be perpetually deferred" ("Part 2" 80), the paradoxically remote yet singularly possible era of Messianic redemption (for it exists outside of the continuum of time) which Benjamin figured as the "angel of history" in Paul Klee's painting Angelus Novus, being irresistibly blown into the future by the storm of progress while he watches the wreckage of the past pile towards the sky has, in Owens's theory of allegory vis-à-vis postmodernism, been redrawn as permanent, deflated impossibility. In place of a constellatory relationship of particulars to produce a dialectical recognition of totality, the postmodern allegorical mode has in its jurisdiction only particulars, which explains its continued import within identity politics. At the turn of the 1980s, allegory had been "revived" as an analytical paradigm for our gain towards understanding the deconstruction of gender in Cindy Sherman's film stills or for Daniel Buren and Michael Asher's uncovering of contemporary art's institutional frameworks. But what have we lost?

\section{Notes:}

\footnotetext{
${ }^{1}$ This has been a philosophical trope since at least Nietzsche: "The various languages placed side by side show that with words it is never a question of truth, never a question of adequate expression; otherwise, there would not be so many languages.... It is this way with all of us concerning language: we believe that we know something about the things themselves when we speak of trees, colors, snow, and flowers; and yet we possess nothing but metaphors for thingsmetaphors which correspond in no way to the original entities" (Nietzsche 82-3).

${ }^{2}$ The process of disenchantment-removing magic and superstition from the worldview-is laid out in its particulars in Weber's seminal study of The Protestant Ethic and the Spirit of Capitalism (1904-5) (see also John Patrick Diggins's Max Weber: Politics and the Spirit of Tragedy). Key to the Protestantspecifically Calvinist-doctrine was predestination, wherein one's fate was foreordained by unknowable divine judgment, and unchangeable through human effort: a refutation of Catholic, and that is to say mystical, worship in the forms of prayers, sacraments, and good works. This left the subject perpetually uncertain and anxious, with the only recourse through assuming that he or she was
} 
"carrying out God's will through a life of discipline and systematic self-control, by an 'inner-worldly asceticism'," an ethic that paved the way for the secularization of life. If this hypothesis seems contradictory, it characterizes Weber's sensitivity to the "irony of unintended consequences," fully realized by 1919 when he expressed that the result of political action regularly "stands in completely inadequate and often even paradoxical relation to its original meaning"; these are not exceptions, but rather "fundamental to all history" (Diggins 99).

${ }^{3}$ As Plate notes, with reference to Shimon Shokek, all myths of creation and destruction reveal also the historical-political realities of the day. Luria's cosmology thus symbolized the experience of the Jewish diaspora, both their original exile from the land of Israel, and their expulsion from the Iberian Peninsula at the end of the Spanish reconquista (1492) of the region (30-32).

${ }^{4}$ Wolin, here, is making a critical point about the popular climate around Benjamin studies.

${ }^{5}$ The discrepancy between Owens's citation and mine owes to two different translations by Harry Zohn, published in Illuminations (1968) and Walter Benjamin: Selected Writings, Volume 4 (2003), respectively.

\section{Works Cited}

Adorno, Theodor W., and Walter Benjamin. "Exchange with Theodor W. Adorno on 'The Paris of the Second Empire in Baudelaire'." Trans. Edmund Jephcott and Michael Jennings. Walter Benjamin: Selected Writings, Volume 4. Ed. Howard Eiland and Michael W. Jennings. Cambridge: Belknap Press, 2003: 99-115. Print.

Benjamin, Walter. Charles Baudelaire: A Lyric Poet in the Era of High Capitalism. 1976. Trans. Harry Zohn. London: Verso, 1983. Print.

---. "The Destructive Character.” Reflections. Ed. Peter Demetz. Trans. Edmund Jephcott. New York: Schocken Books, 1978: 301-3. Print.

--- "On Language as Such and on the Language of Man." Reflections. Ed. Peter Demetz. Trans. Edmund Jephcott. New York: Schocken Books, 1978: 314-32. Print.

--- "On the Concept of History." Trans. Harry Zohn. Walter Benjamin: Selected Writings, Volume 4. Ed. Howard Eiland and Michael W. Jennings. Cambridge: Belknap Press, 2003: 389-400. Print.

---. The Origin of German Tragic Drama. 1963. Trans. John Osborne. London: Verso, 2009. Print.

---. "The Work of Art in the Age of Its Technological Reproducibility: Second Version." Trans. Edmund Jephcott and Harry Zohn. Walter Benjamin: Selected Writings, Volume 3. Ed. Howard Eiland and Michael W. Jennings. Cambridge: Belknap Press, 2002: 101-33. Print. 
Buchloh, Benjamin H.D. "Allegorical Procedures: Appropriation and Montage in Contemporary Art." Art After Conceptual Art. Cambridge: MIT Press, 2006. 27-51. Print.

Buck-Morss, Susan. The Origin of Negative Dialectics: Theodor W. Adorno, Walter Benjamin, and the Frankfurt Institute. New York: The Free Press, 1977. Print.

Caygill, Howard. "Walter Benjamin's Concept of Allegory." The Cambridge Companion to Allegory. Ed. Rita Copeland and Peter T. Struck. Cambridge: Cambridge University Press, 2011: 241-53. Print.

Copeland, Rita, and Peter T. Struck. Introduction. The Cambridge Companion to Allegory. Ed. Rita Copeland and Peter T. Struck. Cambridge: Cambridge University Press, 2011: 1-11. Print.

Crimp, Douglas. “On the Museum's Ruins,” October 13 (Summer 1980): 41-57. JSTOR. Web. 30 Jan. 2014.

---. "Pictures." October 8 (Spring 1979): 75-88. JSTOR. Web. 30 Jan. 2014.

Day, Gail. "Allegory: Between Deconstruction and Dialectics." Oxford Art Journal 22.1 (1999): 105-118. JSTOR. Web. 30 Jan. 2014.

Diggins, John Patrick. Max Weber: Politics and the Spirit of Tragedy. New York: Basic Books, 1996. Print.

Eiland, Howard, and Michael W. Jennings. Walter Benjamin: A Critical Life. Cambridge: Harvard University Press, 2013. Print.

Eiland, Howard, and Kevin McLaughlin. Translators' Foreword. The Arcades Project. By Walter Benjamin. 1982. Trans. Howard Eiland and Kevin McLaughlin. Cambridge: Harvard University Press, 1999: ix-xiv. Print.

Goethe, Johann Wolfgang von. "Maxims and Reflections." Trans. Nicholas Walker. Art in Theory 1815-1900: An Anthology of Changing Ideas. Ed. Charles Harrison, Paul Wood, and Jason Gaiger. Oxford: Blackwell Publishers, 1998: 74-8. Print.

Melville, Stephen. "Notes on the Reemergence of Allegory, the Forgetting of Modernism, the Necessity of Rhetoric, and the Conditions of Publicity in Art and Criticism." October 19 (1981): 55-92. JSTOR. Web. 30 Jan. 2014.

Nietzsche, Friedrich. "On Truth and Lies in a Nonmoral Sense." Trans. Daniel Breazeale. Philosophy and Truth: Selections from Nietzsche's Notebooks of the Early 1870s. Ed. Daniel Breazeale. New Jersey: Humanities Press International, 1979: 79-97.

Obbink, Dirk. "Early Greek Allegory." The Cambridge Companion to Allegory. Ed. Rita Copeland and Peter T. Struck. Cambridge: Cambridge University Press, 2011: 15-25. Print.

Owens, Craig. "The Allegorical Impulse: Toward a Theory of Postmodernism." October 12 (1980): 67-86. JSTOR. Web. 30 Jan. 2014.

---. "The Allegorical Impulse: Toward a Theory of Postmodernism Part 2." October 13 (1980): 58-80. JSTOR. Web. 30 Jan. 2014.

Plate, S. Brent. Walter Benjamin, Religion, and Aesthetics: Rethinking Religion Through the Arts. New York: Routledge, 2005. Print. 
Rosen, Michael. "Benjamin, Adorno, and the Decline of the Aura." The Cambridge Companion to Critical Theory. Ed. Fred Rush. Cambridge: Cambridge University Press, 2004: 40-56. Print.

Roy, Marina. "Speaking in Other Terms: Buchloh's Allegorical Tracings of PostConceptual Constellations." Writing. Marina Roy, 1999. Web. 15 Jan. 2015.

Steiner, George. Introduction. The Origin of German Tragic Drama. By Walter Benjamin. 1963. Trans. John Osborne. London: Verso, 2009. 7-24. Print.

Wolin, Richard. Walter Benjamin: An Aesthetic of Redemption. New York: Columbia University Press, 1982. Print. 